\title{
Study on the Influencing Factors and Marketing Strategies of Purchase Intention of Children's Theme Publications
}

\author{
Wenting Wang \\ School of Journalism and Communication, Anhui University, Hefei 230601, Anhui, China \\ Email: 1258665518@qq.com
}

\begin{abstract}
Children's themed publishing is the key work of children's publishing house. With the support of policy, children's themed publications have prominent social benefits, but at the same time, some children's themed publications a re also facing the dilemma of "popular but not popular". In order to find the key factors influencing the development of consumers' purchase of children's themed publications, this paper empirically analyzes the factors of readers' preference for children's themed publications based on the Sheth-Newman-Gross value consumption model theory. The results show that functional value, social value and economic value are positively correlated with consumers' attitudes towards children's themed books. On the basis of empirical analysis, this paper puts forward some suggestions for marketing strategies of children themed publications.
\end{abstract}

Keywords: children's themed publications, marketing, Sheth-Newman-Gross value consumption model, purchase intention

\section{Research background and problems}

\subsection{Policy support}

Thematic publishing assumes the role of guiding the direction of public opinion and educating the public. Therefore, thematic publishing insists on giving priority to benefit and giving consideration to economic interests. Children's themed books occupy a special position in the field of themed publishing. Children are in the initial stage of the establishment of the three views, so the correct guidance is particularly important. Some publishers have chosen children's publishing as a presidential project. With the support and guidance of policies, the number and quality of children's themed publications are on the rise. However, the publishing industry is facing the pressure of survival and development brought by marketization, and it still needs to take into account the economic benefits on the premise of realizing the social benefits of children's themed publishing. How to better explore the market development potential of children's theme publishing and provide theoretical support for the marketization of children's theme publishing is the key issue of this paper.

\subsection{Market sales}

In the list of dangdang's Top 500 children's books from 2018 to 2020, there are only 5 themed publishing books on the list, accounting for $1 \%$. Although some children's themed publications have high praise rate and bright market performance, children's themed publications still account for a small proportion of the children's book bestseller list. Then, it analyzes the sales of 21 children's themed books (excluding three audiobooks) in Dangdang Books from 2016 to 2020, which are shortlisted for key theme publications. As of August 2020, Dangdang's top three bestselling books were Dawa on the Snow Mountain, published by Bright Day Publishing House, A Chinese Dream for 100 Children, published by 21 st Century Press, and Because of My Father, published by Jiangsu Phoenix Children's Publishing House. Overall, the market performance of some significant thematic publications is mediocre, and low discounts are the norm. E-commerce often raise the price, attract consumers with low discounts, and force the publishing house to supply at lower discounts. In the end, suppliers often bear the cost of discount activities. The publishing house has to reduce costs and increase pricing, which is not conducive to the benign development of the publishing house in the long run.

\section{Theoretical model construction}

\subsection{Relevant theoretical basis}

The Sheth-Newman-Gross consumption value model was proposed by Sheth, Newman and Gross in 1991. The theory of this model evaluates consumers' consumption behavior based on value. It puts forward that the five consumption values of functional value, social value, emotional value, cognitive value and conditional value are the reasons that affect consumers' choice, purchase of a product or loyalty to a brand. 


\subsection{Variables and assumptions}

\subsubsection{Function value}

The functional value factor is the main factor that prompts consumers to make decisions. If a product or label has certain functional attributes, it indicates that the product has functional value. ${ }^{[1]}$ For children's themed books, functional value includes material properties and spiritual attributes, including content quality, use effect and binding design of children's themed publications. Therefore, this paper proposes the hypothesis:

H1a: Functional value has a positive correlation with consumers' choice of children's themed books

H1b: Functional value has a positive correlation with consumers' willingness to purchase children's themed books

\subsubsection{Emotional value}

Emotional value refers to the fact that when consumers choose a certain commodity, they may depend on their own feelings and ideas. This value orientation is often affected by their own political attitude, cultural level and other social attitudes. For example, fans of a brand will feel happy and satisfied when they buy their favorite brand products. Specifically for children's themed publications, that is, consumers' emotions will also affect their willingness to purchase children's themed publications. Therefore, this paper proposes the hypothesis:

H2a: Emotional value is positively correlated with consumers' attitude towards choosing children's themed books

$\mathrm{H} 2 \mathrm{~b}$ : Emotional value is positively correlated with consumers' willingness to purchase children's themed books

\subsubsection{Conditional value}

Conditional value means that under certain circumstances, consumers' consumption psychology and behavior will be affected. This is because the products that generate conditional value will be connected with the prior state of consumers, while external interests and other factors change the original behavior of consumers. In some conditions, it will stimulate consumers' demand and desire, thus leading to purchase behavior, but this conditional value is short-term in nature. Therefore, this paper proposes the hypothesis:

H3a: Emotional value is positively correlated with consumers' attitude towards choosing children's themed books

$\mathrm{H} 3 \mathrm{~b}$ : Emotional value is positively correlated with consumers' willingness to purchase children's themed books

\subsubsection{Social value}

Social value refers to the perceived utility of being able to connect with one or more specific social groups. What consumers care about is whether the product can improve their social status and shape their social image. By analogy with book sales, if a certain book has a good social impact, consumers may think that reading the book will make people around them think highly of them. Therefore, this paper proposes the hypothesis:

H4a: Social value is positively correlated with consumers' attitude towards choosing children's themed books

$\mathrm{H} 4 \mathrm{~b}$ : Social value is positively correlated with consumers' willingness to buy children's themed books

\subsubsection{Economic value}

The price mechanism itself is the most important mechanism in the market mechanism, so the cost performance will affect consumers' decisions. In the downturn of the market economy, the effect of this influencing factor will be more significant. After consumers have a certain understanding and evaluation of product performance, service and price, they will usually judge whether the price is acceptable to users according to their understanding and feeling of product value level. Potential users may be willing to buy children's themed publications because the price is reasonable. Therefore, this paper proposes the hypothesis:

H5a: Emotional value is positively correlated with consumers' attitude towards choosing children's themed books

H5b: Emotional value is positively correlated with consumers' willingness to buy children's themed books

\subsubsection{Cognitive value}

Cognitive value means that consumers' choice depends on whether the product can satisfy their curiosity and pursuit of new knowledge. By analogy to the field of children's themed publications, the cognitive value is mainly reflected in that consumers will evaluate whether children's themed publications meet the audience's demand for knowledge and education. Therefore, this paper proposes the hypothesis:

H6a: Cognitive value is positively correlated with consumers' attitude towards choosing children's themed books

H6b: Cognitive value is positively correlated with consumers' willingness to purchase children's themed books

\subsubsection{Attitude selection}

When users purchase products, the existing purchase experience and will constitute the reference basis of their purchase behavior. If some readers have bought a book published by a certain publisher and think it is of good quality, they may buy other books published by that publisher. Therefore, choice attitude also has an impact on consumers' purchase intention.

H7: Choice attitude is positively correlated with consumers' willingness to purchase children's themed books. 


\section{Empirical analysis}

\subsection{Questionnaire design and data collection}

The empirical part was carried out by questionnaire. The first part is the personal information of the respondents, and the portrait of consumers is drawn by analyzing the data of marriage and childbearing status and purchase status. The second part is scale design. Based on six dimensions such as functional value and emotional value, the likert5-level scale is used to analyze consumer intention analysis. A total of 516 valid questionnaires were collected, of which $49.2 \%$ were male and $50.78 \%$ were female. $44.38 \%$ of respondents said they had heard and understood children's themed publications, and $10.85 \%$ had not heard of them at all. $48.64 \%$ of respondents said they learned about children's theme publishing through the recommendation of their school teachers, and $43.02 \%$ through the recommendation of friends. By analyzing the user portrait of the interviewee. Among the consumers who have bought children's themed publications, people aged 26-35 account for the highest $40 \%$, followed by those aged $36-45$, accounting for $35.71 \%$. Respondents with children between 4 and 8 years old bought the most (24\%), followed by those between 9 and 13 years old (14.9\%). It can be seen that these people are the main consumers of children's themed publications.

Table 1. Potential variables and measurement variables in the questionnaire

\begin{tabular}{|c|c|c|}
\hline Latent variable & Measurement items & Scale source \\
\hline \multirow[t]{3}{*}{$\begin{array}{l}\text { Function value } \\
\text { (FV) }\end{array}$} & FV1: I think children's themed publications are of very good quality & Sweeney; Lin \\
\hline & FV2: I think publishing books on children's topics is very well done & \\
\hline & $\begin{array}{l}\text { FV3: I think the use effect of children's themed books is consistent with the } \\
\text { description }\end{array}$ & \\
\hline \multirow[t]{3}{*}{$\begin{array}{l}\text { Sentimental value } \\
\text { (QV) }\end{array}$} & QV1: Buy kids' themes because kids love them & \\
\hline & QV2: I think reading children's themed publications will bring happiness to children & \\
\hline & QV3: I think children will feel relaxed when they read children's themed publications & \\
\hline \multirow[t]{3}{*}{$\begin{array}{l}\text { Conditional value } \\
\text { (TV) }\end{array}$} & TV1: When there is a promotion, I buy children's themed publications & Lin \\
\hline & TV2: If I can experience the products, I will choose children's themed publications & \\
\hline & $\begin{array}{l}\text { TV3: When schools and teachers require it, I will buy children's themed books for } \\
\text { my children }\end{array}$ & \\
\hline \multirow[t]{3}{*}{$\begin{array}{l}\text { Social value } \\
\text { (SV) }\end{array}$} & SV1: Buying children's themed publications will give others a good impression & Sweeney \\
\hline & $\begin{array}{l}\text { SV2: By buying and reading children's themed publications, children will get more } \\
\text { social recognition }\end{array}$ & Lin \\
\hline & $\begin{array}{l}\text { SV3: Reading children's themed publications will make children better integrate into } \\
\text { society and The Times }\end{array}$ & \\
\hline \multirow[t]{3}{*}{ Economic value(JV) } & JV1: 3I buy children's themed publications that I think are reasonably priced & Sweeney \\
\hline & JV2: I can accept the price of children's themed publications & Lin \\
\hline & JV3: I think children's publications are worth the money & \\
\hline \multirow[t]{3}{*}{$\begin{array}{l}\text { Cognitive value } \\
(\mathrm{RV})\end{array}$} & $\begin{array}{l}\text { RV1: Before buying children's themed publications, I will get to know all kinds of } \\
\text { relevant information }\end{array}$ & Lin \\
\hline & $\begin{array}{l}\text { RV2: By reading children's themed books, children can acquire the knowledge they } \\
\text { need }\end{array}$ & \\
\hline & $\begin{array}{l}\text { RV3: Reading children's themed publications can help children establish a correct } \\
\text { view of the three }\end{array}$ & \\
\hline \multirow[t]{3}{*}{$\begin{array}{l}\text { Choice } \\
\text { (CA) }\end{array}$} & CA1: I think publishing books on children's topics is very attractive & \\
\hline & CA2: I think it's good for children to publish books with children's themes & \\
\hline & CA3: I think children's themed books are the must-read books for children & \\
\hline \multirow[t]{3}{*}{$\begin{array}{l}\text { Purchase intention } \\
(\mathrm{PI})\end{array}$} & PI1: I buy children's themed publications & \\
\hline & PI2: I would recommend children's themed publications to my friends or relatives & \\
\hline & PI3: I think it's a trend to buy children's books & \\
\hline
\end{tabular}




\subsection{Reliability and validity analysis}

\subsubsection{Reliability analysis}

Reliability and validity are important indexes to measure whether the questionnaire is scientific and reliable. The reliability is represented by the reliability coefficient. The larger the reliability coefficient is, the higher the reliability of the scale is, and the more consistent the measured value of the questionnaire is with the measured target value.

Table 2. Reliability test table of measurement model

\begin{tabular}{ccc}
\hline Variable & Items & Cronbach's Alpha \\
\hline Function Value & 3 & 0.739 \\
Sentimental Value & 3 & 0.715 \\
Conditional Value & 3 & 0.78 \\
Social Value & 3 & 0.721 \\
Economic Value & 3 & 0.706 \\
Cognitive Value & 3 & 0.733 \\
Purchase Intention & 3 & 0.784 \\
Choice attitude & 3 & 0.756
\end{tabular}

The reliability test results of the formal questionnaire are shown in the table above. It can be seen from the table that Cronbach values of all variables are above 0.7 , showing good reliability, indicating that the design of the questionnaire scale in this study is reasonable and reliable, and the measurement results of the scale can truly reflect the thoughts of the respondents.

\subsubsection{Validity analysis}

Validity indexes can be divided into three categories: content validity, standard validity and structure validity. This paper adopts the empirical research method to analyze the content validity and structure validity through the collected questionnaires. Content validity measures the rationality of scale question design. Structural validity refers to the extent to which the characteristics of a variable can theoretically be measured in a scale. The measurement of structural validity of questionnaire includes aggregation validity and discriminative validity.

The aggregation validity can be analyzed by factor load value, combined reliability value and mean variance extraction value. ${ }^{[2]}$ When the factor load value is greater than 0.7 , the combined reliability value is greater than 0.8 , and the mean variance extraction value is greater than 0.5 , the scale can be considered to have good aggregation validity. Through the measurement of aggregate validity, the results are shown in Table 4. The external factor load values of each measurement item in the scale are all greater than 0.7 , the combined reliability of the measurement value of the scale is all greater than 0.8 , and the average extraction variation, namely the extraction value of the mean variance, is all greater than 0.5 . Therefore, it can be concluded that the questionnaire has good aggregate validity.

Table 3. Aggregation validity test table

\begin{tabular}{|c|c|c|c|c|}
\hline Variable & Measurement item & External factor load & Composite Reliability & Average extraction of variation(AVE) \\
\hline \multirow[t]{3}{*}{ Choose Attitude } & CA1 & 0.875 & 0.859 & 0.671 \\
\hline & $\mathrm{CA} 2$ & 0.775 & & \\
\hline & CA3 & 0.804 & & \\
\hline \multirow[t]{3}{*}{ Function Value } & FV1 & 0.858 & 0.852 & 0.658 \\
\hline & FV2 & 0.744 & & \\
\hline & FV3 & 0.826 & & \\
\hline \multirow[t]{3}{*}{ Economic Value } & JV1 & 0.759 & 0.874 & 0.628 \\
\hline & JV2 & 0.806 & & \\
\hline & JV3 & 0.811 & & \\
\hline \multirow[t]{2}{*}{ Purchase Intention } & PI1 & 0.86 & 0.874 & 0.698 \\
\hline & $\mathrm{PI} 2$ & 0.796 & & \\
\hline
\end{tabular}




\begin{tabular}{lcccc}
\hline Variable & Measurement item & External factor load & Composite Reliability & Average extraction of variation(AVE) \\
\hline \multirow{3}{*}{ Sentimental Value } & PI3 & 0.85 & 0.874 & 0.637 \\
QV1 & 0.83 & & \\
QV2 & 0.76 & 0.652 \\
QV3 & 0.804 & 0.874 & \\
Sognitive Value & RV1 & 0.799 & & 0.642 \\
RV2 & 0.799 & 0.874 & \\
RV3 & SV1 & 0.824 & & \\
& SV2 & 0.842 & & \\
& SV3 & 0.792 & & \\
& TV1 & 0.767 & & \\
\hline
\end{tabular}

Discriminant validity refers to the correlation coefficient between latent variables. In general, when the square root of the extracted mean variance of variables is greater than the correlation coefficient between variables, it indicates that the discriminant validity is good. ${ }^{[3]}$ According to the results of discriminant validity analysis of the scale in this study, it can be seen that there is a significant relationship between latent variables and latent variables in Table 5, and the square root of average extracted variation (AVE) extraction values are all greater than the correlation coefficient between latent variables, indicating that the discriminant effect of measurement items of different variables in this model is qualified.

Table 4. Discriminant validity analysis table

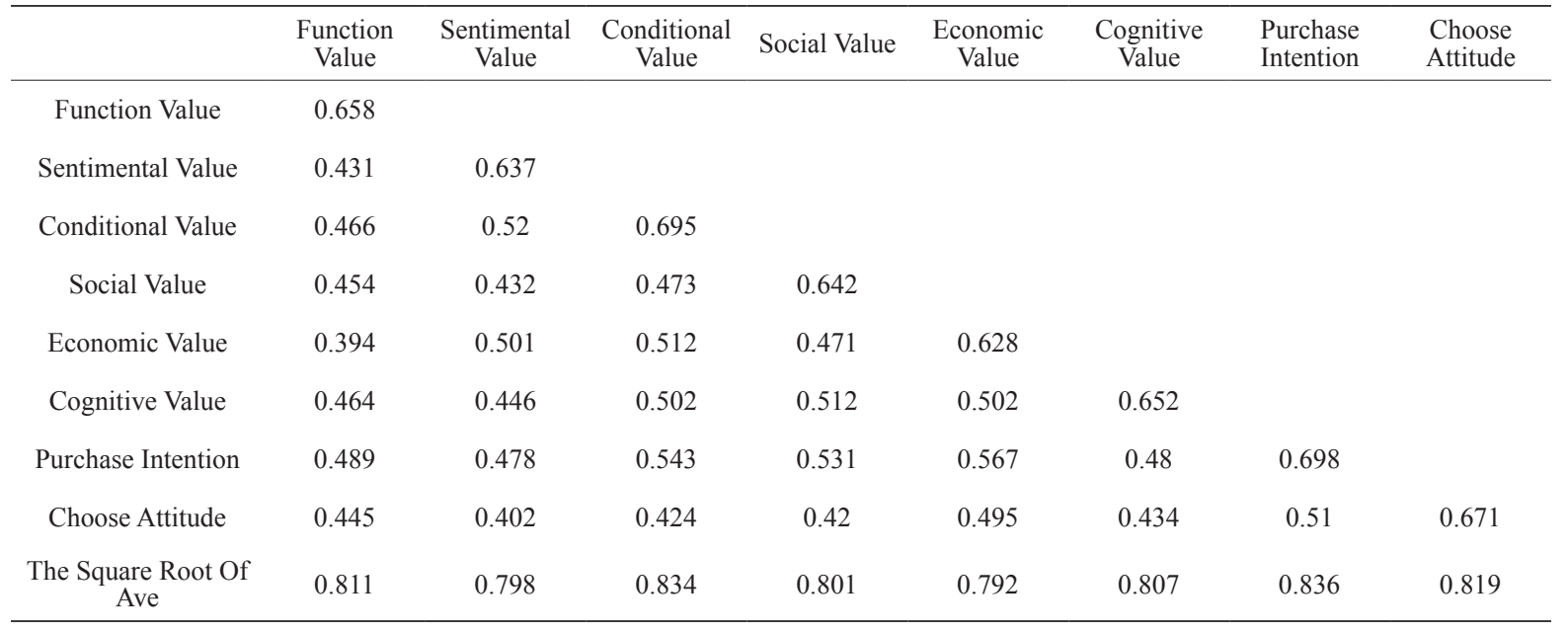

\subsubsection{Structural model and verification results}

In this study, the Bootstrapping algorithm of non-parametric estimation in Smartpls software was used to test the significance of the model path coefficient. Generally, when P value is greater than 0.05 , the relationship is not significant, when $\mathrm{P}$ value is less than 0.05 , the relationship is significant, and when $\mathrm{P}$ value is less than 0.01 , the relationship is very significant. The significance analysis results of path coefficients are shown in the following table. 


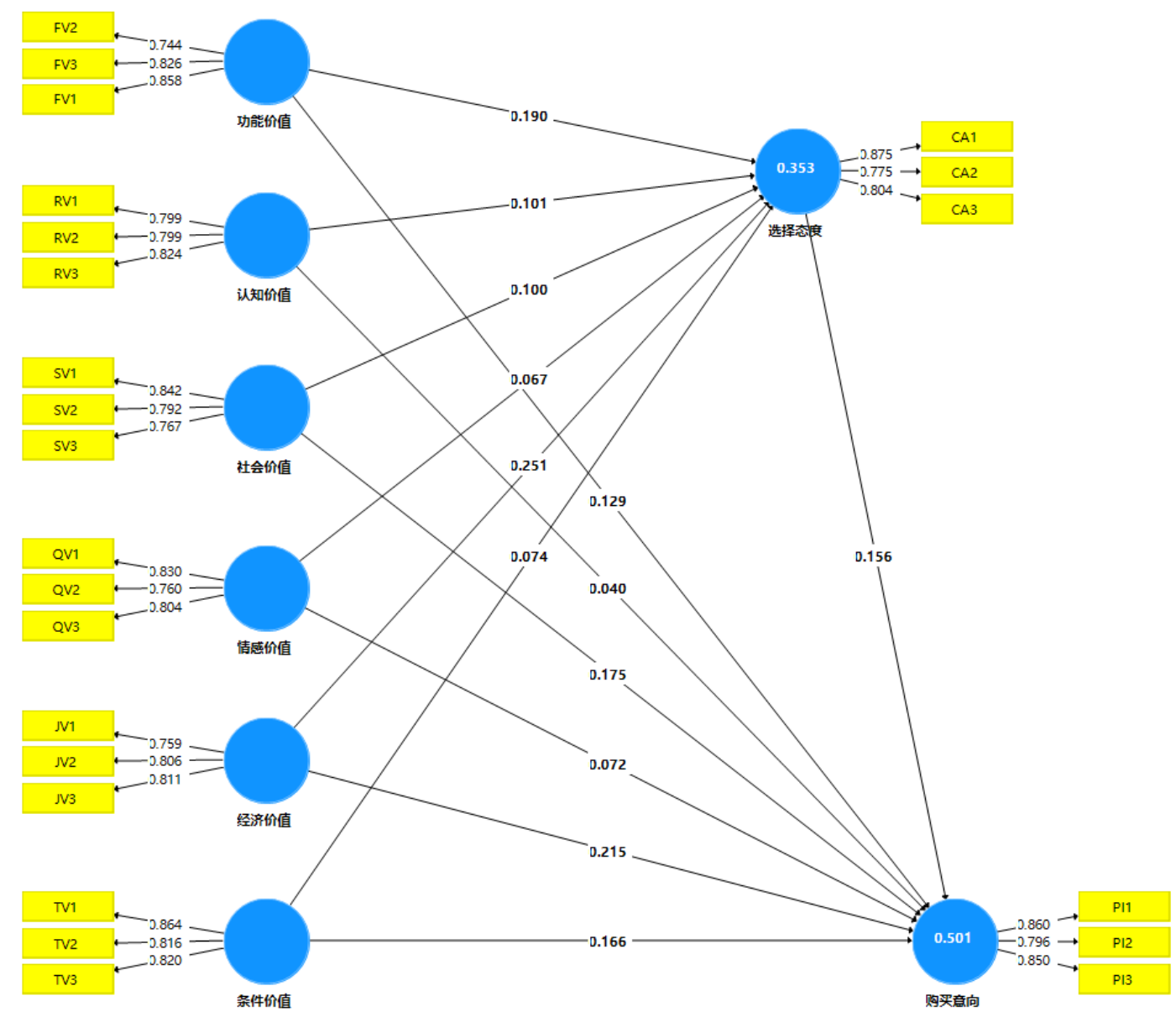

Figure 1. Model itting evaluation result diagram

According to the fitting evaluation analysis, the final hypothesis test results can be obtained.

Table 5. Summary of hypothesis testing results

\begin{tabular}{lccccc}
\hline \multicolumn{1}{c}{ Hypothesis } & $\begin{array}{c}\text { The original } \\
\text { sample }(\mathrm{O})\end{array}$ & Mean value $(\mathrm{M})$ & $\begin{array}{c}\text { Standard deviation } \\
(\text { STDEV })\end{array}$ & P value & Results \\
\hline H1a Functional value $\rightarrow$ purchase intention & 0.129 & 0.129 & 0.045 & 0.004 & Support \\
H1b Function value $\rightarrow$ choice attit & 0.19 & 0.19 & 0.051 & 0 & Support \\
H2a Emotional value $\rightarrow$ purchase intention & 0.072 & 0.072 & 0.038 & 0.057 & Without support \\
H2b Emotional value $\rightarrow$ choice attitude & 0.067 & 0.069 & 0.048 & 0.159 & Without support \\
H3a Conditional value $\rightarrow$ purchase & 0.166 & 0.168 & 0.047 & 0 & Support \\
intention & 0.074 & 0.073 & 0.06 & 0.221 & Without support \\
H3b Conditional value $\rightarrow$ choice attitude & 0.175 & 0.174 & 0.04 & 0 & Support \\
H4a Social value $\rightarrow$ purchase intention & 0.1 & 0.103 & 0.049 & 0.043 & Support \\
H4b Social value $\rightarrow$ choice attitude & 0.215 & 0.214 & 0.05 & 0 & Support \\
H5a Economic value $\rightarrow$ purchase intention & 0.251 & 0.249 & 0.049 & 0 & Support \\
H5b Economic value $\rightarrow$ choice attitude & 0.04 & 0.04 & 0.049 & 0.413 & Without support \\
H6a Cognitive value $\rightarrow$ purchase intention & 0.101 & 0.101 & 0.054 & 0.061 & Without support \\
H6b Cognitive value $\rightarrow$ choice attitude & 0.156 & 0.156 & 0.041 & 0 & Support \\
H7 Choice attitude $\rightarrow$ purchase intention & & & &
\end{tabular}


According to the results, functional value, social value and economic value are positively correlated with consumers' attitudes towards children's themed books, while the hypothesis that emotional value, cognitive value and conditional value have an impact on consumers' attitudes towards children's themed books is not supported.

\section{Conclusions and recommendations}

According to empirical analysis and data verification, functional value, social value and economic value have a significant positive impact on promoting consumers to purchase children's themed publications, while emotional value and cognitive value do not play a significant role, indicating that these factors have a small role in promoting the purchase of children's themed publications at the present stage. This has to do with many consumer stereotypes about themed publications. Based on the research results of this paper, the following countermeasures and suggestions are put forward for the market optimization of children's themed publications.

\subsection{Guarantee the quality of children's themed publications}

Only sincere works can gain the recognition of readers. For example, "Dawa on Snow", a children's publication with military themes on Tibet border, has won more than 10 important awards, such as the "Five One Project" award of the 15th Spiritual Civilization Construction by the Propaganda Department of the CPC Central Committee, and the Best Copyright Content Creation Award of China copyright Association in 2020.Recently, it made the list of "my favorite children's books of 2020", which was selected by 33 libraries and voted by 200, 000 children. The book has sold more than 150,000 copies cumulatively. The key to this book's economic and social benefits lies in its quality. When writing this book, the author Qiu Shanshan once shuttled back and forth to the Tibetan Plateau more than 10 times, in the border defense corps, posts and other places of field interviews, so the plot of the book is sincere and touching. The writer kept in touch with the editor and changed his draft three times. It can be seen that a real double-effect book is full of ingenuity.

\subsection{Adhere to the social value of children's themed publications}

Sticking to the social value of children's themed publications is still the core task. CSC has published a series of children's themed publications with social value and good market sales. ZhongShaoShe theme publishing project "less sunlight in the library was chosen as" published "much starker choices-and graver consequences-in" national key project of the plan, the project in order to "learn as a child, since the childhood learning encourage ambition, from learning to create" social orientation as the goal, the editor has published a series of conforms to the different age levels the theme of the young children to read books. ${ }^{[4]}$ The Story of The Scientist picture book series selects touching examples of 10 scientists such as Yuan Longping and Tu Youyou, which are vivid and interesting yet affectionate. In terms of artistry, the paintings are mainly made with originality, with a vivid and realistic style and strong appeal. This series of books can help children set the right example and develop the right outlook on life and values.

\subsection{Improve the interest of children's themed publications}

Children's theme publishing books should not only become children's reading tasks, but also should let children like to read, want to read, as lightly to tell children the feelings of family and country become the difficulty of children's theme publishing. At present, the main type of children's themed publications is still children's literature, while picture books, toy books and other types are less. Ma Xingmin, general manager of The China Children's Press and Publication Agency, believes that planning should meet children's needs for emotional resonance, entertainment or imagination enhancement. Use such as picture books, audio books, toys and other forms to enhance the fun of books, in the publication of games, toys, cultural and creative products and other design, novel books with entertainment functions are more likely to attract the interest of young children, so that children in the process of listening to stories, hands-on practice to experience the fun of reading theme published books. ${ }^{[5]}$

\subsection{Enhance the knowledge of children's themed publications}

More than half of the respondents believe that children cannot acquire the knowledge they need by reading children's themed books. In fact, education and knowledge can be closely combined. For example, Duan Lixin and Sun Rui, the authors of "Juvenile Space Administration" published by Relay Publishing House, repeatedly confirmed knowledge points with space experts in the process of writing the book to ensure that the content is correct, and then vividly reproduced the whole process of manned spaceflight from ground training to in-orbit operation with the story. The book contains a lot of aerospace knowledge, with more than 50 extensions at the back of each volume. 


\subsection{Strengthen three-dimensional publicity and marketing of children's themed publications}

Wine is also afraid of deep alley, a good book to be seen by more readers, in addition to the traditional word-of-mouth marketing, but also need to take a three-dimensional marketing model. In addition to traditional channels, publicity efforts can also be strengthened through wechat public accounts, little red books, short videos and live broadcasts. 2021 is the 100th anniversary of the founding of the Communist Party of China, Anhui Fine Arts Publishing House will carry out the "Children's Heart to the Party 2021 Anhui Children's Painting and Calligraphy Competition", not only to let young readers have a sense of participation, but also to promote a series of children's themed publications. Various channels and forms of three-dimensional propaganda can play a positive impact of cognitive value on consumers' purchase intention.

\section{References}

[1] Dou Jinhua. Research on Affective Value in Brand Recognition[C]. Hunan University, 2006.

[2] Li Jinjun, Hu Pei. Research on the transformation of consumption-driven economic growth pattern — The framework of consumer participation measurement model[J]. Research on Economics and Management, 2012,(09):33-40.

[3] Feng Changli, Han Yuyan. An empirical study on the relationship between sharing intention, communication and knowledge sharing effect from the perspective of supply chain[J]. Soft science, 2012,26(4):48-53.

[4] Zhang Xiaonan.How to Polish the Brand of Children's themed books[EB/OL]. 2019-11-11/2019-11-11.

[5] Liu Beibei.Dialogue with principals of seven children's clubs - How to make achievement in children's theme publishing [EB/OL]. 2021-4-19/2021-4-19. 